\title{
Miranda
}

Revue pluridisciplinaire du monde anglophone /

Multidisciplinary peer-reviewed journal on the English-

speaking world

$20 \mid 2020$

Staging American Nights

\section{After Hours, Through the Night: Jazz Poetry and the Temporality of Emergence}

\section{Audrey Goodman}

URL: http://journals.openedition.org/miranda/24424

DOI: 10.4000/miranda.24424

ISSN: 2108-6559

Publisher

Université Toulouse - Jean Jaurès

\section{Electronic reference}

Audrey Goodman, "After Hours, Through the Night: Jazz Poetry and the Temporality of Emergence

", Miranda [Online], 20 | 2020, Online since 24 March 2020, connection on 16 February 2021. URL:

http://journals.openedition.org/miranda/24424 ; DOI: https://doi.org/10.4000/miranda.24424

This text was automatically generated on 16 February 2021.

\section{(c) (i) () $\Theta$}

Miranda is licensed under a Creative Commons Attribution-NonCommercial-NoDerivatives 4.0 International License. 


\title{
After Hours, Through the Night: Jazz Poetry and the Temporality of Emergence
}

\author{
Audrey Goodman
}

\section{Opening Bars: Listening in the Dark}

1 To experience a version of the cool exhilaration of a mid-twentieth-century American jazz night, one might start by listening to an iconic Miles Davis recording that both specifies and extends the parameters of midnight. Davis first recorded his version of "Round Midnight," a Thelonious Monk composition, with tenor saxophonist Sonny Rollins, bassist Percy Heath, saxophonist Charlie Parker, pianist Walter Bishop, and drummer Philly Joe Jones for Prestige Records in January 1953. But it was his performance of the piece at the second Newport Jazz Festival in 1955, following Parker's death, that really made Davis's name, bringing him sudden fame and a recording contract with Columbia Records (Early 213-4; Giddens 341). Playing and riffing on the melody in his pure style, working from an arrangement by Gil Evans, Davis created an expressive yet muted sound that communicated "an impression of lyric indifference to the world" and "an image of the world" itself, in the estimate of jazz historians Berendt and Huesmann (120). Mixing modes of "aggression and melancholy" (120), it extended each phrase so as to blur the boundaries between beginnings and endings and to convey the wild desire for transformation as well as sober reflection on the hard realities of the present. There are qualities of unpredictability and inevitability in Davis's version of the song. His horn "seems to come of nowhere" and unexpectedly "fades into nothingness." His sound, "apparently so fragile and timid, contains an incisive intensity" (124). As Gregory Corso writes in his tribute poem "For Miles," "Your sound is faultless / pure \& round / holy / almost profound" (114). 
2 Performed originally by Black musicians, appropriated and commodified by whitedominated entertainment industries, and reinvented through collaboration and live performance, jazz music such as that performed by Davis provides a powerful means of exploring the politics and the formal innovations of modernist art in the twentieth century. Beginning with close attention to listeners' responses to this decisive performance by Davis in the early 1950s, this essay explores how musicians and jazz poets set critical precedents for Davis's innovations. Then the essay follows the complex legacies of Davis and other jazz musicians into contemporary poetry, focusing on how Native poets have also claimed blues and jazz as inspiration for their writing and as models for voicing struggles against racism, injustice, and coloniality. Through attention to selected examples of jazz poetry by Langston Hughes and Joy Harjo (Muscogee Creek), I aim to show how Black and Native jazz poems reconfigure relationships among musicians, listeners, writers, and their readers as they cross racial, cultural, and gender divides.

3 By the time he performed "Round Midnight," Davis already excelled at soloing and arranging and at linking musical styles. According to Gerald Early, Davis created both East Coast hard bop and West Coast "cool" (or white musician's) jazz.

To the yang of hard bop Davis brought stillness, melodic beauty, and understatement; to the yin of cool he brought rich sonority, blues feeling, and an enriched rhythmic capacity that moved beyond swing to funk. (Early 155)

4 Although his stance "toward the white world was totally unconciliatory" (Berendt and Huesmann 131), Davis was very popular with white listeners, many of whom might have bought only one jazz album: Davis's revolutionary yet accessible Kind of Blue. As his career continued, Davis kept adapting his approach though listening to and learning from other innovative musicians, revealing jazz's reliance on collaboration and its distinctive sociality. To borrow a characterization from pianist Brad Mehldau, jazz is "collective improvisation." When Meldau thinks of Davis or John Coltrane, he thinks of "the way that they relate to each other as a group. That's the spirit of jazz music" (qtd. in Berendt and Huesmann 656).

Even as Davis's social legacy was been fiercely debated, his music continued to resonate across many social and cultural boundaries. To advocates of the "free jazz" movement of the 1960s, such as Amiri Baraka, Davis's popularity with whites and interracial affiliations compromised the revolutionary potential of his music. To black women, Davis's misogyny and his record of domestic violence compromised, if not destroyed, his iconic status. Even so, Davis's music has spoken powerfully to many different listeners. Despite the controversy over his behavior, black women have responded to and performed his compositions. Singing like a voice, his horn seems to promise safety and understanding, Farah Griffin writes in "Ladies Sing Miles," an essay that begins with her account of Davis's deep inspiration: an old Black churchwoman whose voice reached him through the Arkansas night. "While walking along a country road, a boy named Miles was moved by a black woman's singing," she writes. "Her voice, an indelible part of the southern night, floating like ghosts through the trees, would haunt his playing throughout his life" (182). In this essay Griffin also pays tribute to all the female performers who made his sound their own, including Shirley Horn and Cassandra Wilson. Perhaps it is this woman's voice, transformed into Davis's signature sound, that led his music to connect with so many listeners and performers over the years. When listening to Davis, Griffin she speculates, "Perhaps we hear something akin 
to our own voices" (182).

For Muscogee Creek poet Joy Harjo, the recorded sound of Davis's horn constituted an essential part of her youth and a source for her poetry. In an interview with Eugene Redmund, a poet associate with the Black Arts movement, Harjo recalls, "His trumpet sound is indelible in my music memory" (25) and describes

how his horn came through the car radio, to the outside, around and inside of me as I stood on the floorboard, perched behind my father who smelled of old Spice. I traveled freely in that sound into the future, beyond the body. When I returned, I was a kid standing behind her father in Oklahoma, in his car bought with what was left of his family's Creek Indian oil money. (Redmund 26)

In an interview with Susan Hobby in 2009, Harjo confirms that "a jazz riff on the radio" was "the first piece of poetry [she] recognized" (Hobby 78). Hearing Davis and other jazz musicians taught Harjo to feel the qualities of melody and experience an expressive power that transcends race; it also prepared her to write poetry that moves between Creek culture, where music belongs to everyone and "isn't a spectator sport" (Redmund 27), and mainstream American culture, which tends to isolate and commodify cultural production. Griffin's testimony and Harjo's recollection confirm that Davis's horn has soared through many nights, voicing many languages at once and creating what Griffin calls “space for a woman's tears, vulnerability, anger, love, sexuality, creativity: a space simply to be" (Griffin 182).

The way that Davis's sound resonated with many audiences, near and far, exemplifies jazz's expressive mobility. Davis's influence as a musician traveled across racial and gender boundaries, transmitted through both the ever-changing improvisation of live performances and the recordings that casual listeners and other musicians would play again and again. The capacity to integrate styles and audiences, which intensified in Davis's sound at this critical moment in the mid-1950s, characterizes the work of many jazz performers and jazz poets who sought to express private and collective anguish simultaneously.

8 Kevin Young writes in his introduction to the anthology Jazz Poems that jazz "is a journeyman's music, not just because it was first performed in Storyville sporting houses, or in nightclubs, but because the music itself undertakes a journey" (Young 11). Its experimental forms create new sensations of connection across generations, regions, and continents and unify disparate listeners. For example, in the poem "Satchmo, U.S.A," inspired by Louis Armstrong and included in his collection Testimony, Yosef Komunyakaa visualizes Armstrong delivering "buckets of coal / to Storyville's red-light houses" (Komunyakaa 29) in his native New Orleans, not far from Bogalusa, Louisiana, where Komunyakaa grew up. Suddenly, his speaker gazes up at the sky and discovers "your face is mine" (29). He sees in the evening star not only Armstrong's face and horn but also the path connecting the many places Armstrong performed:

You

are holding a bugle

in your first cutting contest

with fate. From back o'

town to the sphinx

\& Buckingham Palace,

to the Cotton Club 
\& soccer fields in Africa, under

spotlights with Ella \& Billie

one hundred nighttimes sweated up

from Congo Square. (29-30)

In "February in Sydney," another recent poem included in Testimony, Komunyakaa's speaker writes down all the music he hears inside his head while walking in the city at night: "Dexter Gordon's tenor sax," Round Midnight, and the sounds of other "Painful gods" who "jive talk through / bloodstained reeds \& shiny brass. .." (37). When his speaker notices "a woman who grabs her red purse / \& hugs it to her like a heart attack" (37) upon seeing him exit from a theater, he finds himself thrust back into social reality, but he also imagines how Gordon would have responded to the woman's racist gesture of fear at seeing a black man: "Tremolo. Dexter comes back to rest/ behind my eyelids" (37). For listeners such as Komunyakaa's speaker who carry the music in their minds and bodies, jazz voices can express shared histories of personal and social struggle.

Jazz travels in many forms: initially through live performances, then through vinyl recordings, radio broadcasts and compact discs, and now through streaming services and podcasts. Each mode creates different networks and opportunities for responding to the music's emotional and spiritual calls. An early example of how performances reached diverse audiences is Duke Ellington's "From the Cotton Club" broadcasts: they were national, beginning in 1928. ${ }^{1}$ By April 1933, 45 radio stations played Ellington's show, a record for those beginning at midnight. "From the Cotton Club" created a broad public audience for jazz and a means of sharing the expressive sounds of American nights with listeners across the country.

With the spread of sound recordings, relationships between performers and listeners became simultaneously more mediated and more intimate. Throughout my childhood in the 1970s and early 1980s, my parents played jazz most evenings, favoring recordings made by older performers such as Ella Fitzgerald, Louis Armstrong, and Jack Teagarden. It was a break from the rhythm of the day and the structure of classical music. Although the effect of the music was immediate, our living room felt far from the places where jazz was performed (even if Armstrong's house in Corona Queens, now a major jazz museum with a rich archive, and the Village Vanguard and the Blue Note, jazz clubs in Greenwich village, were just a train ride away). Rather than the thrill of live performance, records such as those my parents played at home created a time for listening and contemplation in private. ${ }^{2}$ Now, in our current digital era, listeners can stream any "live" recording they choose through public radio stations or other delivery services and project the music into any private space through speakers or directly into the body through earbuds; they control the spatial scope and the sociality of their listening.

11 Sound technologies continue to multiply the possibilities for mediating and manipulating relationships between performers and listeners and the experiences of time on both ends. Consequently, attention paid to the sense of time conjured by the jazz voice, the actual and imagined locations of the performances themselves, the sources of an artist's inspiration, and the process of signifying on and transforming these sources can all contribute to a more complete understanding of jazz's intimate 
and improvisational poetics. Readers of jazz poetry who analyze the dynamic relations between musicians and their audiences can then listen more intently to both the aural dimensions of printed poems and the multiple temporalities and traditions invoked in this broad genre of writing. ${ }^{3}$

In the remainder of this essay, I investigate the places where jazz voices emerge, analyze the meanings of darkness, and listen for the ways that jazz poetry articulates deep connections between Black and Native artists and their musical cultures. While Black poets adapted the structures of blues, spirituals, and sorrow songs, Native "musicians combined the ancient traditions of song as 'medicine/power' to contemporary styles of music and venues of dissemination to advance the survival and continuation of Indian existence" (Johnson 93). If modernity is defined by recurrent ruptures across social formations that cause myriad forms of dislocation, to quote from Susan Friedman's powerful analysis in Planetary Modernisms, the modernist forms of jazz poetry that respond to such conditions can enact "creative relocations" (Friedman 62). By exploring the sonic and cultural routes that connect Black and Native histories, readers and listeners can apprehend the cultural work of such remapping. ${ }^{4}$

\section{First Set, Langston Hughes: Writing Beyond Midnight}

To me jazz is a montage of a dream deferred. A great big dream-yet to come-and always yet-to become ultimately and finally true. [. . .] Jazz is a heartbeat-its heartbeat is yours. You will tell me about its perspectives when you get ready. ${ }^{5}$ Hughes, "Jazz as Communication"

The earliest examples of jazz poetry by Langston Hughes show keen awareness of jazz music's potential for inciting formal experiments with voice and for bringing together diverse listeners. While not the first poet to write about jazz, Hughes "was arguably the first to fully embody a jazz aesthetic" and to succeed in "capturing the language of jazz, its very grammar" (Young 12). Consider Hughes's 1924 "Jazz Band in a Parisian Cabaret."

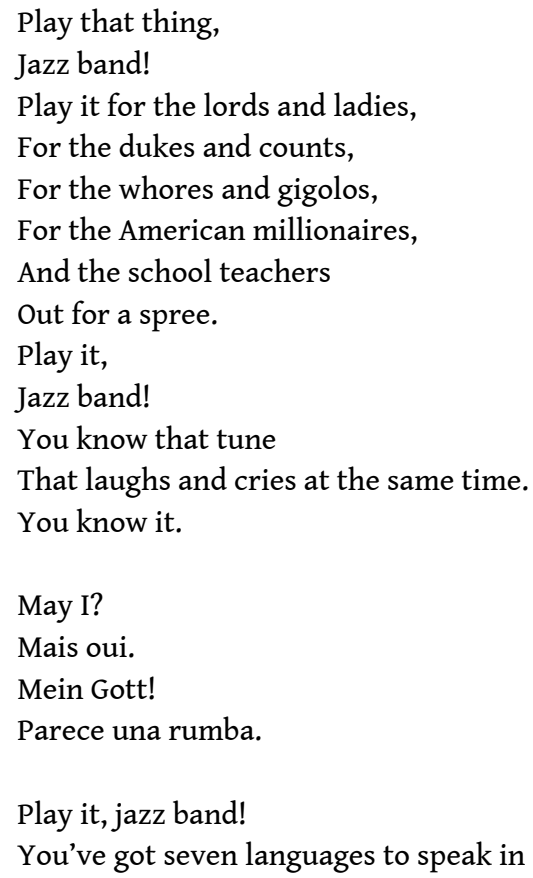


And then some,

Even if you do come from Georgia.

Can I go home wid yuh, sweetie?

Sure. (Hughes 1994, 60) speakers and languages that overlap in a jazz performance. It records the confusing sounds of a multilingual audience and the audience's request for a blues tune that "laughs and cries at the same time," a tune that could speak to listeners of all races, classes, and nationalities. While acknowledging the band's roots in the U.S. South, the poem itself is "a singular evocation of Hughes's expatriate experience," according to Brent Edwards (64); it articulates the transnational mobility of both jazz's audiences and the music itself. In addition, the poem identifies a particular night space in which jazz flourished: Le Grand Duc cabaret on 52, rue Pigalle in Montmartre, a nightclub owned at the time by African American boxer Eugene Bullard, where Hughes worked washing dishes. The club attracted top performers and celebrity audiences, from the Prince of Wales to Cole Porter, Charlie Chaplin, and F. Scott Fitzgerald. Edwards reads this poem as an expression of many, often contradictory desires. As he explains, the poem's

last lines attempt to hold at least two things together in a fragile balance: on the one hand, an individual listener's affective connection to the music, and, on the other, the collectivity of listeners the music allows, the connections it fosters. (Edwards 67)

The form itself-with its fragments of different languages, its staccato cries, and its indented lines corresponding to the speakers' varied locations-bridges the gap between an actual social space and the utopian community that might take shape when the imagined tune is finally played.

While Paris would be an important social space for jazz, in Hughes's writing Harlem more frequently provides direct inspiration for how performers and listeners connect to create new collectivities. Harlem and its music defined Black life in the early twentieth century, Hughes claims in his 1926 essay "The Negro Artist and the Racial Mountain." Hughes further identifies urban jazz as both the inspiration for his own poetry and, more generally, a mode of revolt against expectations of productivity and other foundations of middle-class white culture:

In many of [my poems] I try to grasp and hold some of the meanings and rhythms of jazz. [. . .] But jazz to me is one of the inherent expressions of Negro life in America; the eternal tom-tom beating in the Negro soul--the tom-tom of revolt against weariness in a white world, a world of subway trains, and work, work, work; the tom-tom of joy and laughter, and pain swallowed in a smile. [. . . ] Let the blare of Negro Jazz bands and the bellowing voice of Bessie Smith singing Blues penetrate the closed ears of the near-intellectual until they listen and perhaps understand. (Hughes 2002, 35-6)

Harlem generated a "cabaret school" of writing, defined by Shane Vogel as "a subterranean literary tradition within the Harlem Renaissance that provided new ways of performing, witnessing, and writing the racial and sexual self" and rebelling "against the politics of normative racial uplift" (5). Hughes originated this "tradition" in the 1920 s and remained one of its primary practitioners. 
Better than any Harlem Renaissance author-perhaps better than any authorHughes captures the special temporality and contact of nightlife in his writing and captures them in a way that leaves such experience unclosed and "in solution." (Vogel 130) of writing, Hughes also provided critical models for composite literary forms and links
between generations of radical artists. ${ }^{6}$ Hughes's writing from the 1940s, the "Simple stories" revolving around protagonist Jesse B. Semple and the poems collected in Montage of a Dream Deferred, further articulated Harlem as a critical location for Black artists and activists. Hughes's determination to create a broad audience for poetry then led to the central tenets of the Black Arts Movement of the 1960s and 1970s: the cultivation of new relationships between artists and their communities, direct communication, and the belief that music constituted the most powerful form of Black aesthetic production. ${ }^{7}$

Beginning with Hughes, writers of jazz poetry claimed night as a creative time when the strict laws of progression relaxed and as their communal space; throughout the night, they could recalibrate the passage of time and listen to clashing, chaotic languages, as well as to silence. They could tarry with the edges: those transitional times such as dusk, midnight, and dawn and those boundaries between private and public experience and between dominant and marginalized cultures. As poets responded to the experience of listening to jazz and integrated the voices they heard in music into their writing, they heightened both the symbolic values of darkness, night, sleep, and the counter-values of light, morning, awakening, and transformation. Opposed to the routine progression of day and working hours, for Black and Native jazz poets the "after hours" came to signal resistance to the regulation of laboring bodies and to the social and economic expectations of productivity. They use the bounded nature of night as a dramatic strategy to create a sense of urgency that propels listeners towards the boundaries of freedom and into the realm of transformation marked by the break of dawn. By layering many temporalities through which their histories could be accessed and new identities could emerge, jazz poets have created spaces of expressive freedom, spaces "simply to be," where the "lower frequencies" continue to resonate.

21 Through poems created from the sounds, languages, and music that mingled in the shared social and public spaces of Harlem nights, Hughes improvised conversations among evolving groups of performers, audiences, and everyday folk. Hughes's Harlembased jazz poems inject energy into representations of work, and joy into the pain of everyday struggles. They initiate journeys through many nights and across continents, penetrating through the darkness of deep or historical time and habitual racism, journeys often propelled through "breaks" in the music. These poems' speakers approach night as a time that promises an interval of leisure and escape from the surveillance of employers or urban observers, but they also bring the speakers face to face with dark personal and collective histories. Many are set at moments of transition, as in "Lenox Avenue: Midnight."

The rhythm of life

Is a jazz rhythm,

Honey.

The gods are laughing at us.

The broken heart of love, 


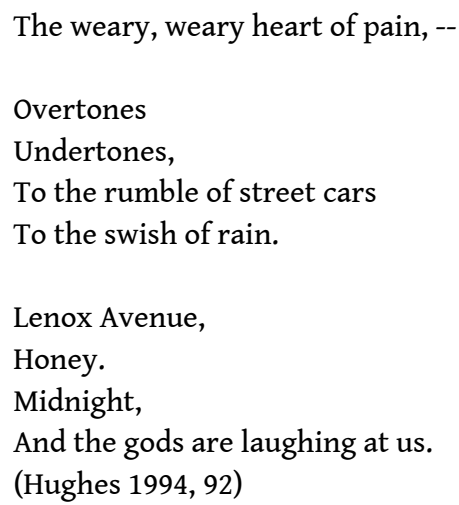

This poem marks a time in the middle of life, characterized by ease and lightness. It unites the speaker and his companion as they occupy the active city, determined to overcome heartbreak and impervious to any larger plan the gods might have for them.

However, in the writing of Hughes and other jazz poets, midnight and the hours that follow often usher in a more intense dream time characterized by sustained contradiction and suspended logic. Midnight marks a threshold between linear and dream time, as in Komunyakaa's poem "The Plea." The poem begins:

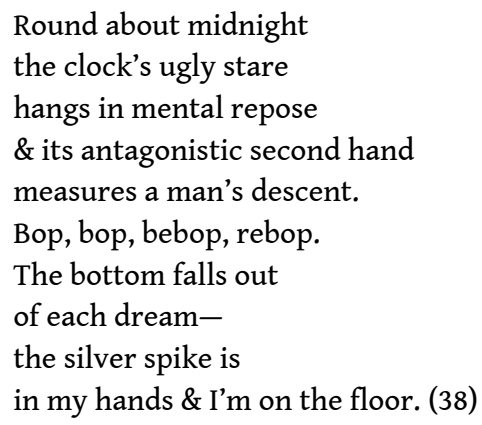

Later, the hour around midnight marks the time when despair is extended so far it almost creates pleasure, or "rapture":

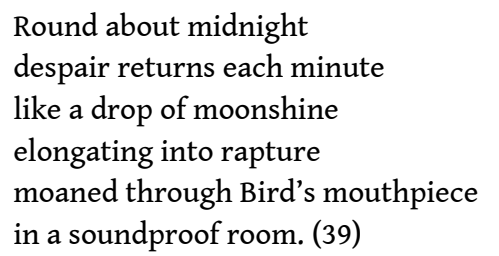

As night progresses, the dreams get darker. Hughes's poetry explores how senses of time and mood shift through the passage of the hours. After midnight, the confrontations between hope and reality intensify as Hughes's speakers contend directly with disappointment and sorrow. Consider "Boogie: 1 a.m.," which opens with the line "Good evening, daddy! / I know you've heard / The boogie-woogie rumble / of a dream deferred" (Hughes 1994, 411). After midnight, the speaker recognizes the effects of an unrealized desire through rhythm and sound, a "boogie-woogie rumble." When he greets a companion, he speaks of their shared recognition that, once again, they will have to wait to realize their dreams.

Two a.m. marks the time when Hughes's speakers struggle to elongate the night as they reckon with the implications of its ending. At that hour, sounds and perspectives start to collide, often creating a feeling of profound despair. In "Reverie on the Harlem 
River," for example, the speaker addresses the reader, seeking affirmation that he is not alone as he voices his losses and confronts his despair.

Did you ever go down to the river-

Two a.m. midnight by your self?

Sit down by the river

And wonder what you got left? (Hughes 1994, 262)

Here Hughes inverses the sequence of night hours and redefines two a.m. as the speaker's own "midnight." The second stanza specifies the sources of the despair implied in the first:

Did you ever think about your mother?

God bless her dead and gone!

Did you ever think about your sweetheart

And wish she'd never been born? (263)

In the poem's final stanza, he sets the exclamations "Midnight!" and "By your self!" in successive lines, heightening their alliance and thus dramatizing the speaker's fundamental loneliness:

Down on the Harlem River:

Two a.m.

Midnight!

By your self!

Lawd, I wish I could die -

But who would miss me if I left? (263)

Caught between the loss of his mother and his romantic struggles, Hughes's speaker finds himself caught in his own "midnight," doubly alone and struggling with his own desire for companionship and enduring love.

Other poems by Hughes locate the rhythm of night in lively social spaces and mimic a jazz club's feverish, chaotic atmosphere. Unlike the solitary setting on the banks of the river, "The Cat and the Saxophone (2 a.m.)" refers to a cabaret (possibly Le Grand Duc, the inspiration for "Jazz Band," or a cabaret on upper Fifth Avenue known as Ed Small's Sugar Cane (lub). In this poem, the voices of performers and customers mingle in the after hours, as Hughes indicates by alternating the lyrics of the 1924 song "Everybody Loves My Baby, but My Baby Don't Love Nobody but Me" by Jack Palmer and Spencer Williams (indicated in capital letters) with an ongoing conversation between two lovers.

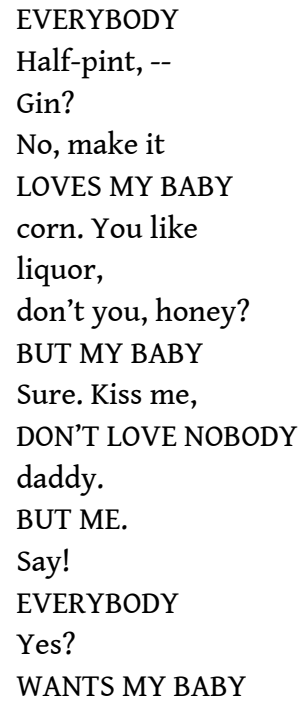




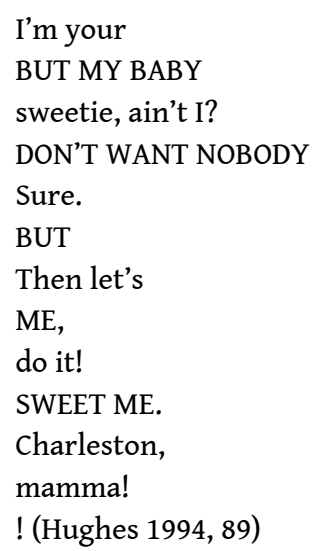

31 As Vogel notes, the poem's unusual typography captures "the improvisation, sound, and sociality of the jazz club" while the evocation of a musical performance creates a free space in which the couple can emerge and dance (Vogel 122). When the singer insists that his "baby" only wants him, the couple determines to express their devotion to each other: "Then let's do it! Charleston, mamma!" The final "!" marks extra effort, extra energy, and the willful displacement of any hard realities. There is only this moment, the moment of exclamation.

However, such spaces and occasions of possibility, willed into being in the after hours, are short-lived, as careful reading across Hughes's body of work reveals. The next hour, 3 a.m., exposes threats of surveillance and the dangers of queer nightlife. The poem "Café: 3 a.m." describes "Detectives of the vice squad / with weary sadistic eyes / spotting fairies," whom "some folks" call "Degenerates" (Hughes 1994, 406). The morning after any wild night can bring new regrets, if not full-blown despair. Still, in other night poems Hughes keeps the tone light. The poem "Bad Morning" laments the speaker's mismatched shoes, while the poem "Morning After" rewrites any traumas brought on in the night as merely the effects of the speaker's companion's incessant snoring (Hughes 1994, 248). In these quotidian settings, dawn illuminates the reality of poverty and daily struggle. In Vogel's reading, dawn also marks the end of night's alternate temporality and its "fugitive sociality." "For Hughes, this end of the night stands for nothing less than an allegory for death, a transition in which he glimpses a haunting timelessness," Vogel claims (124). Perhaps because he knows that the transformative possibilities of night cannot be sustained, Hughes also writes poems that confess his speaker's desire to erase the memories of both desire and disappointment. He confesses in the poem "Blues at Dawn," for instance, "I don't dare remember in the morning / Don't dare remember in the morning / If I recall the day before, / I wouldn't get up no more- / So I don't dare remember in the morning" (Hughes 1994, 420).

33 The transition in feeling at the end of night is captured especially well in Hughes's "Summer Night," a poem that in Vogel's words "archives the ephemerality of loss, absence, and emptiness that marks the departure from the tempo and hope of the cabaret" (128). Appreciate how the first stanza conveys the night winding down and prepares the reader for the silence that emerges just before dawn:

The sounds

of the Harlem night

Drop one by one into stillness.

The last player-piano is closed. 
The last victrola ceases with the

"Jazz Boy Blues." (Hughes 1994, 59)

Then Hughes injects suspense: what will come next? Not action, not entertainment, but a mixture of feelings: fatigue, emptiness, loss of possibility, desire, restlessness, longing, anticipation of dawn, fear that the new day will bring just more of the same. Perhaps all of these feelings will surface and dissipate at different rates, with some fleeting instantly and others sticking around. This particular summer night opens an interval for listening to the reverberations of silence; written as a jazz poem, it provides space on the page for feelings that might otherwise remain elusive or unexpressed.

The poem's conclusion also heightens the reader's awareness of the symbolic power of whiteness, represented in the last stanza as a ubiquitous presence that resists the closure of night and obscures the speaker's vision:

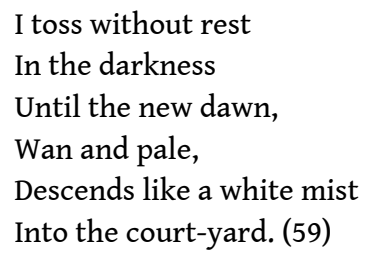

Dawn's light in this concluding image seems both weak (wan and pale) and oppressive (in its descent towards the court-yard), mild yet irrevocable. Containing the diffuse residue of unresolved feeling, this new dawn hardly promises radical transformation. Yet, if we accept the claims advanced by Paul Gilroy and elaborated by Paul Anderson that Black popular music "fuses the power of musical remembrance to a utopian critique of the present" (Anderson 212-213), Hughes's jazz poetry can be viewed as accomplishing the dialectical work that defines Black aesthetics. It captures the urgent sensations and languages of night while leaving open "utopian anticipation of a better world in the future" (Anderson 212).

Reading "Summer Night" in conversation with his later reflections in the address "Jazz as Communication" presented at the 1956 Newport Jazz Festival further reveals how, for Hughes, jazz comes to serve as a democratic model for voicing many different, if not fully realized, possibilities (Hughes 2002, 368-70). Instead of playing a "tom-tom of revolt," as Hughes initially conceptualized the oppositional function of jazz "The Negro and the Racial Mountain," he addresses all of humanity and summons an inclusive vision of "a great big dream-yet to come" (Hughes 2002, 370). Characterizing jazz as both "a heartbeat" and "a great big sea" that "washes up all kind of fish and shells and spume and waves with a steady old beat, or off-beat," he incorporates here a longer history of listening. In this address, Hughes expands the reach of jazz music, imagining that it could include all the forces of nature. While in Hughes's later poetry the "great big dream" may remain suspended in the dark, concealed by the "white mist" that arrives with each "new dawn" (Hughes 1994, 59), his jazz nights continue to imagine those spaces and temporalities in which darkness can be felt, named, and mapped.

\section{Second Set, Joy Harjo: Traveling through the Breaks of Day}

Whenever a saxophone begins to sing in a story we know that for a time, we will no longer move about so lonely here, far away from the house of the sun, moon, and 
stars. $^{8}$

Harjo, Conflict Resolution for Holy Beings distraction from the mundane everyday world," nor were they "high art" (Bergland, Johnson, and Lee 5). Songs have the power to shape the world: to bring rain or a productive harvest, to restore health, and to heal divisions in a community. "Songs define who people were/are." (6) Native writers such as Ofelia Zepeda (Tohono O'odham) and Luci Tapahonso (Diné) often approach poems as songs on the page, structuring stanzas like verses, incorporating rhythmic refrains, and mixing melodic and spoken languages. They "do what is required to communicate the stories that need to be told as historical correctives or social commentary" (Diamond 20). For Native poets writing during the occupation of Alcatraz in 1969 and afterwards, the incorporation of jazz elements into written poetry has additionally provided a means for resisting colonial narratives and articulating relations among multiple and intersecting communities, traditions, languages, and audiences. As Gabriela Raquel Rios argues in her persuasive essay on Harjo included in Indigenous Pop, a collection of new scholarly work on Native American music, the inclusion of song, sounds, and other performance elements in a poem can disrupt linear storytelling and work together on a printed page "as a way of enacting healing a decolonial practice" (Rios 108). Explaining such strategies of protest more generally, Sean Teuton claims, "During the era of Red Power, Native writers imagined a new narrative for Indian Country, and they did so neither by longing for an impossibly timeless past nor by disconnecting Indians' stories from the political realities of their lives" (Teuton 2).

In her poetry, Harjo adapts the rhythms of urban jazz and Muscogee ceremonial music (such as that played for the stomp dance and the Green Corn ceremony) to disrupt modern clock time and recalibrate the idea of progress. Since childhood, jazz music seemed to take her "to the birth of sound." She learned as an adult that her grandmother Naomi Harjo had played saxophone in Indian Territory in Oklahoma, but her own exposure to jazz music began with radio broadcasts. Listening to the car radio while driving at night with her father, she heard jazz musicians make "a startling bridge between familiar and strange lands," connecting African, European, and Muscogee traditions. This experience of listening constituted her "rite of passage into the world of humanity" and exemplified "a way to speak beyond the confines of ordinary language (Feinstein and Komunyakaa 1996, 212-13).

Harjo's musical education continued when she frequented jazz clubs in Boulder, Colorado and heard the inventive fusion of Kaw/Creek saxophonist Jim Pepper (Harris 113). Then, while in her thirties, Harjo began to play saxophone herself. As she explains in the interview with Redmond, "The horn sounds like a human voice, a laughing and crying human voice. Poetry on the page wasn't enough for me" (Redmund 28). The saxophone seemed particularly capable of bridging human and celestial worlds and opening pathways towards "the house of the sun, moon, and stars" (Harjo 2015, 91). She formed a band, Poetic Justice, and she recorded the albums Native Joy for Real (2004), Winding Through the Milky Way (2008), and Red Dreams, A Trail Beyond Tears (2010). She now creates performances that mix stories, songs, music, poetry and dance, including the evolving one-woman show published as the play Winds of Night Sky, Wings of Morning Light (2019) and a musical play currently in development, We Were There When Jazz was Invented. Harjo views both the page of a book and the stage as "dreaming spaces," with "their own set of natural laws of aesthetics, form, and manners of movement" (Harjo

Miranda, 20 | 2020 
$2015,56)$. In the words of critic Robin Fast, "The cross-cultural improvisations and creative dialogism that Harjo hears in jazz, and that she writes into her poetry, challenge [...] any illusion of cultural survival in stasis" (Fast 161).

While jazz music offers critical languages of expression and resistance for Black artists in the U.S., it also provides a means to explore histories of cultural exchange and potential alliances between Black and Native musicians and writers. Harjo started writing and playing saxophone when the Black and Red Power struggles for civil, human, and Indigenous rights provided strong motivation for linking politics and poetics. Many other jazz musicians have Native roots, including Mildred Bailey, Charlie Parker, Don Cherry, Lena Horne, and Jim Pepper. ${ }^{9}$ It is important to remember, too, that the places at the center of African American culture where jazz originated were also Indigenous homelands; enslaved people were brought to live in the Mississippi Delta, lands occupied by Muscogee, Chickasaw, and Choctaw communities. As Chickasaw scholar Jodi Byrd contends, blues and jazz voices reveal shared colonial histories of displacement. Nonetheless, this music can activate "the processes of renewing a place-world" and bring new "spatial relations" into being (Byrd 118).

Many of Harjo's poems respond directly to the powerful performances of her favorite musicians and use them to guide her own path through the night and towards a renewed articulation of home, a unifying goal of the Red Power movement. She transfers each musician's sound into her speaker's body and onto the page; as she seeks new routes through the dark, she indicates that the difficult process of emergence into an alternative world will call on musical and other forms of memory. ${ }^{10}$ In her tribute poem to Kaw and Creek saxophone player Jim Pepper, "The Place the Musician Became a Bear," Harjo contrasts the steady illumination of the moon and the stars with the saxophone's unpredictable tune. "Our souls imitate lights in the Milky Way. We've always known where to go to/become ourselves again in the human comedy," she writes. "It's the how that baffles. A saxophone can complicate things." (Harjo 2002, 114) Pepper himself mixed and complicated things, as Harjo indicates in her explanatory note following the poem.

Jim was a fine tenor and soprano jazz saxophonist and, at the urging of Don Cherry and other musicians with whom he played, had begun constructing a music that married the traditional elements of jazz with Muscogean and Plains tribal musics. (Harjo 2002, 224)

Best known for the song "Witchi Tai To" and the album Pepper's Pow Wow (1971), Pepper synthesized the music he listened to during late-night radio broadcasts with songs and intertribal dances of pow wow circuit, the music of Kaw Peyote Church and "that of other indigenous nations with Jazz, rock, country, R\&B, and other pop forms" (Siegel 47). The sound of the horn connects all of his experiments in fusing musical styles. Later in the poem, Harjo asserts again, "The wings of the Milky Way lead back to the singers. /And there's the saxophone again" (Harjo 2002, 115).

In responding to Pepper's music, Harjo's speaker mixes a vision of the moon with sounds of the city as she experienced them when visiting Pepper in Brooklyn, just as Hughes did in "Midnight: Lenox Avenue." She "listened to the sax gods of Ben Webster, Cannonball Adderley, and his other inspirations and influences, talked Oklahoma and home," and heard "the subway beneath his apartment building shaking the world like a huge underground snake" when "he'd disappear for his fix" (Harjo 2002, 224). As she writes in the poem, "It's about rearranging the song to include the subway hiss/under 
your feet in Brooklyn. /And the laugh of a bear who thought he was human" (115). Her version of the song dramatizes her struggle to accept the uncertainty and constant motion of contemporary life: it's "the one about the wobble of the earth / spinning so damned hard / it hurts" (115).

With the poem "Bird," Harjo's tribute to Charlie Parker, the brilliant and selfdestructive saxophone player with Choctaw roots on his mother's side, Harjo joins a diverse group of writers who idolize Parker for his improvisations, his bop blues aesthetic, and his frantic, drug-fueled quest (Feinstein and Komunyakaa 1996, 92-3). Harjo's poem begins:

The moon plays horn, leaning on the shoulder of the dark universe to the infinite glitter of chance. Tonight I watched Bird kill himself,

larger than real life. I've always had a theory that some of us are born with nerve endings longer than our bodies. Out to here,

farther than his convoluted scales could reach. Those nights he played did he climb the stairway of forgetfulness, with his horn,

a woman who is always beautiful to strangers? All poets

understand the uselessness of words. We are chords to

other chords to other chords, if we're lucky, to melody. [. . .] (Harjo 2002, 73)

Written in response to Parker's astonishing virtuosity and drive, "Bird" wonders how close to the sky Parker could climb with his "convoluted scales." It imagines Parker, an artist "born with nerve endings longer than our bodies," following the music to "the place those nerve endings dangle" (73). Parker's fingers may be "hot from miracles," but they're too reckless to remember what it takes to survive. Ralph Ellison famously wrote that Parker "stretched the limits of human contradiction beyond belief" (67), and Harjo follows him to those limits. ${ }^{11}$

In Harjo's poem, Parker becomes more than a musician; he offers access to the moon, the force that creates music itself. Countering such luminous energy, however, are the darker currents of pain, self-destruction, and madness to which Parker's playing also provides access: "Each rhapsody embodies counterpoint" (73) Harjo writes. With pain as its foundation, this is no easy romance: "pain stuns the woman / in high heels, the man behind the horn, sings the heart" (73). While the poem articulates the exhilaration of letting the music extend the body's limits of sensation, it also voices the danger of going too far: "Tonight I watch Bird kill himself, / larger than life" (73) Or: "To survive is sometimes a leap into madness" (73) In the end, the speaker calls out to anyone outside listening in the dark, calling for a response that might bring Bird "home."

While shaped by Davis, Pepper, and Parker, Harjo consistently the strongest affinity with John Coltrane because of his sound and his profession of "love supreme" late in his career. "I have always loved John Coltrane because of what I feel in his music," Harjo claimed in a 2018 interview with Diné poet Sherwin Bitsui. "He went directly to the origin of creation" (Bitsui 2018). In the tribute poem "Healing Animal" included in Feinstein and Komunyakaa's anthology The Second Set she declares,

[...]I want to make a poem that will cup

the inside of your throat

like the fire in the palm of a healing animal. Like

the way Coltrane knew love in the fluid shape 
of a saxophone

that could change into the wings of a blue angel.

He tasted the bittersweet roots of this crazy world,

and spit them out into the center of our musical

jazzed globe. (Harjo 1996, 66-7)

In this poem, Harjo considers Coltrane as an artist capable of nearly infinite innovation:

"Your music is a crystal wall with a thousand mouths, kin to trains and sounds that haven't yet been invented" (67), she writes. Then she extends into her own writing Coltrane's message of love and forgiveness (expressed fully in Love Supreme, the album Coltrane created after overcoming addiction), a message that carries revolutionary force because it both offers balm to the voice straining to sing and shows how music can transform the world. Her "jazzed globe" pulses with the power of animal beings capable of healing trauma and the vibrations of life.

In her tributes to jazz musicians, Harjo confronts the knowledge generated through listening and traveling through the night; her own jazz poems further test the measures and meanings of darkness. Consider the untitled prose poem, "Midnight is a Horn Player," from Conflict Resolution for Holy Beings. This poem riffs on each dark hour:

Midnight is a horn player warmed up tight for the

last set. One a.m. is a drummer who knows how to lay

it sweet. Two a.m. is a guitar player who is down on

his luck. Three a.m. is a bass player walking the floor

crazy for you. Four a.m. is a singer in silk who will do

anything for love. Five a.m. is kept for the birds. Six

a.m. is the cleaning crew smoking cigarettes while they

wait for the door to open. Seven a.m. we're having

breakfast together at the diner that never closes. Eight

a.m. and we shut it down, though the clock keeps

running, all through the town. (Harjo 2015, 41)

51 Here midnight marks the middle of the night, the elastic boundary between clock time and dream time. Through the poem's rational and inevitable progression towards sunrise, Harjo charts the mood and attitude of each jazz musician. She reserves one hour near sunrise, 5 a.m., "for the birds" and another, 6 a.m., for "the cleaning crew smoking cigarettes while they wait for the door to open." Dawn arrives in the middle of this shift, but the momentum of the night keeps the band going through to breakfast at an all-night diner and the "clock keeps / running / all through the town."

Critical and imaginative engagement with the dark, the rhythms of night, and the transformative potential of sunrise run through all of Harjo's performances, recordings, and printed collections, linking her writing to traditions of jazz poetry created by African American poets like Hughes and Gwendolyn Brooks. The poem "3 AM," originally published in 1973, describes a night in which she and a companion find themselves "in the Albuquerque airport / trying to find a flight to Old Oraibi, Third Mesa," their "center/of the world" (Harjo 2002, 8). With all the help desks closed, they find themselves stranded and realize that they are "just two Indians /at three in the morning / trying to find a way back." Three a.m. is late. But it is "not too late / to find the way back," she concludes (Harjo 2002, 8). Even after hours of waiting, Harjo's speaker still holds out hope that they will make it home.

53 The poems set at night, in bars or other forsaken places, create stages for exploring inner darkness, doubt, and despair, and they dramatize her desire to emerge into and inhabit an alternate world that might also lead back to Muscogee lands. In a prose 
poem published in Conflict Resolution, "We Were There When Jazz Was Invented," Harjo stretches and bends the temporality of night to encompass a return "all the way back," to the beginning of creation.

I have lived 19,404 midnights, some of them in the quaver of fish dreams.

And some without any memory at all, just the flash of the jump

From a night rainbow, to an island of fire and flowers-such a holy

Leap between forgetting and jazz. (Harjo 2015, 21)

The speaker then jumps into that other realm and stomps "All night, / beyond midnight, back / Up into the sky, holy" (21). Eventually, when she finds the path "all the way back / To the stomp grounds where jazz was born," it's still "holy" midnight (23). For Harjo, discovering one's identity through relation to place requires playing in the dark as a condition for finding the right way to greet the morning and return home. As she writes, remembers, and creates the rhythms of the night in her poetry, she reenters the darkness of her struggle against violence and oppression. Her work insists that it is necessary to confront the realities of America's dark past; only then is it possible to heal the ruptures caused by coloniality and to access a world unbounded by their legacy.

Harjo's recent jazz poem “An American Sunrise," published first in Poetry in February 2017 and revised for her most recent collection with the same title, An American Sunrise (2019), similarly confronts the darkness of night and coloniality before greeting dawn with a fight against the removals and alienation forced on Native peoples: ${ }^{12}$

We were running out of breath, as we ran out to meet ourselves. We were surfacing the edge of our ancestors' fights, and ready to strike. It was difficult to lose days in the Indian bar if you were straight.

Easy if you played pool and drank to remember to forget. We made plans to be professional - and did. And some of us could sing so we drummed a fire-lit pathway up to those starry stars. Sin was invented by the Christians, as was the Devil, we sang. We were the heathens, but needed to be saved from them - thin chance. We knew we were all related in this story, a little gin will clarify the dark and make us all feel like dancing. We had something to do with the origins of blues and jazz I argued with a Pueblo as I filled the jukebox with dimes in June, forty years later and we still want justice. We are still America. We know the rumors of our demise. We spit them out. They die soon. (Harjo 2017)

While this poem acknowledges temptations to forget (to lose days by drinking and playing pool), it foregrounds acts of remembrance and advocates for collective action. It recalls unspecified fights of the speaker's ancestors and alludes to the early days of the Red Power movement (forty years later and we still want justice). It speaks of concepts imposed by colonizers ("Sin") and then refutes them; it speaks of manufactured distractions (gin) and then reclaims them as tools for seeing through the dark. The edges of lines and line breaks are abrupt, but as the speaker continues she demonstrates that the pain can be overcome. Instead of accepting "the rumors of our demise," this speaker "spit(s) them out," using the repetition of the first-person plural pronoun ("we") as a steady beat to affirm the survival of Native people." The last word, "soon," brings revolutionary transformation within reach.

"An American Sunrise" follows the model of the "Golden Shovel," a new form invented by poet Terrance Hayes in which the last words of each line are taken from another 
poem, most often one by Gwendolyn Brooks. Harjo's poem riffs on Brooks's iconic “We Real Cool," a jazz lyric first published in Poetry magazine in 1958 about fast-living kids playing pool in a bar:

We real cool. We
Left school. We
Lurk late. We
Strike straight. We
Sing sin. We
Thin gin. We
Jazz June. We
Die soon. (Brooks 73)

Tightly constructed from monosyllabic words and employing techniques of alliteration, assonance, rhyme and repetition, "We Real Cool" dramatizes the vulnerability of youth and the power of a Black collective consciousness. In an interview with Studs Terkel, Brooks explains, "the 'we' is supposed to be almost attached to the word that precedes it, and it's to indicate a song of lost-ness and a sort of bewildered clutch at identity, a sort of-a little cry" (Brooks, P.S. 29). The collective speaker of the poem keeps playing, keeps moving to the next game - until the game is up with death's sudden approach, underscored by the abrupt absence of the pronoun "We" in the last line.

It seems that Brooks's voice and the relentless rhythm she created in this poem lodged itself in Harjo's memory and kept reminding her to fight for a different outcome. Commenting on the "fresh and vital" effects of "Golden Shovel" poems, Poetry magazine editor Don Share explains,

The results of this technique can be quite different in subject, tone, and texture from the source poem, depending upon the ingenuity and imagination of the poet who undertakes to compose one. [...] [s] uch a poem is part cento, part erasure. But don't let the word "erasure" mislead you. A poem in this form adds something even where it subtracts. (Share 2017)

61 What Harjo adds in "An American Sunrise" is the comparative context that lets her readers see the struggle for survival and justice shared by African American and Native youth, as well as a more expansive form of storytelling. Through quoting directly from Brooks's poem at the end of every line, Harjo rewrites the poem, visually rearranging it into a jagged vertical form and changing the rhythm. Instead of the inexorable beat of "We Real Cool," Harjo works the breaks as pauses, introducing the possibility that her "we" might not make it through the night. ${ }^{13}$ She responds to Brooks's warning by resolving that she and her after-hours companions will resist the dangers of artificial nights. With her "Golden Shovel" poem, Harjo simultaneously pays tribute to Brooks and adapts the jazz form to assert shared histories of struggle and to imagine a collective route toward a better future. ${ }^{14}$

62 A distinctive drive in Harjo's writing is the urgent desire to keep traveling towards dawn, light, and home. Rather than lament the ephemerality of darkness, her speakers fight to understand and dispel it. "This is what makes Harjo's poetry so optimistic," Muscogee Creek and Cherokee writer Craig Womack explains, "-not only does she critique oppressive systems, but she is able to imagine their absence" (230). Another example of Harjo's drive to imagine new territory is evident in the first part of A Map to 
the Next World, named "Songline of Dawn." A poem at the center of this section, "Emergence," begins in the middle of a "midsummer night," with its speaker "lingering at the edge / of a broken heart" (29). As the speaker feels her heart "coming apart," she also remembers an earlier time, a time before coloniality caused people "to cut the land or each other into pieces, / when we knew how to think / in beautiful" (29). This night work, which is the work of confronting pain, fragmentation, and dislocation, also confirms her desire to think beyond the limits of "small things" and the boundaries of the known world. It can conjure a vision of a newly "surfacing" world and "locate the sense beyond desire" (29). In the end, it strengthens her resolve: "I will locate the point of dawning / and awaken / with the longest day in the world" (30), she announces.

To experience the renewal promised by sunrise, however, requires careful preparation. In Conflict Resolution, Harjo recalls many occasions when she returns to ancestral grounds. As Womack explains in connection to another poem by Harjo,

'To go home' [. . .] is the state of the Native Union where the hoop is no longer broken, lands are returned, people are in control of their own resources; in other words, going home to vibrant Native nationalism, to real self-determination (231).

Harjo's recent poems map routes back to Muscogee homelands through the sounds and rhythms of the stomp dance. With her relatives, she dances not only all night but all summer, absorbing the power of the sun during its strongest season and circulating from one stomp ground to another, "sharing food, songs, and nights that made concentric circles of stories on the road to sunrise" (Harjo 2015, 52). Here the nights put stories in motion and create paths towards the dawn; what makes such creative harmony possible are the sustained and reciprocal exchanges between people and the songs and dances they perform. By creating moving circles, the people generate a collective rhythm, explore night's dark, unmapped spaces, and map spiral routes towards decolonial spaces.

Finally, listeners and readers can apprehend well the intertwined processes of cultural exchange and collaboration at the center of jazz poetics through comparing two versions of Harjo's "Goin' Home (song)," recorded as the last track in Winding Through the Milky Way (2008) and printed in a central section in Conflict Resolution (2015) ${ }^{15}$ In the book, Harjo introduces the song with a prose recollection of returning to her ancestral grounds; the song is followed with an explanation of the Muskogee ceremony that ushers in each new year by seeking harmony between plant, animal, and human worlds. This sequence creates a specific context for understanding the song and the correct place for listening to it. Intended to accompany the "last dance" of the night on the last night the year, it carries the singers and the listeners through to a new beginning, which is also the recovery of a harmonious world. The poem begins,

Last dance and the night is almost over

One last round under the starry sky

We're all going home someway, somehow when it's over

Hey e yah, hey e yay aye e yah aye e yay (Harjo 2015, 53)

The singer then recognizes that, no matter where they are, everyone wants not only romantic love but a great and transcendent love, "a love supreme," even if they have "married sixteen times." The lyrics address many forms of love-romantic, erotic, familial, cosmic-and advise listeners to remember their ancestors and to keep the touch steady and light: "Don't forget: hold somebody's hand in the dark" (54); "If you've found love in the circle then hold onto it, not too tight / If you have to let love 
go then let it go - Keep on dancing" (53). The singer urges her listeners to stay connected and to "figure out how to get our homelands back" (53).

In its directives, allusions, verbal instructions, and rhythm, "Goin' Home" confirms critical connections between this poet and the Native traditions and jazz musicians who inspired her. The title of the poem circles back to Pepper's best-known recording, "Witchi-Tai-To," and its composition echoes that work's mixture of "Manhattan jazz riffs with stomp dance rhythms" (Lincoln 360). The words at the center of the poem, as well as the jazz rhythms that introduce the performed version, allude to and extend John Coltrane's late masterwork, A Love Supreme (1964). Uttered as a refrain in this new context, its declaration of "a love supreme" surges across generations, cultures, and performative spaces, re-emerging as an urgent invitation to follow the jazz horn players into new territory. Although this night ends with an ordinary valediction, "Good night, sleep tight," the singer won't let sleep efface memory: "Don't forget: hold somebody's hand through the dark" (54), she admonishes. Then she returns to the refrain "Goin' home goin' home" (54), as if willing it to continue and enact a definitive, collective return.

Whereas the recorded version of "Goin' Home" ends with instruments taking over from the singing voice and continuing to play through the final bars, the printed version of the poem concludes with four lines in Muscogee. These lines ask non-Muscogee readers to sound out an unfamiliar language without knowing its meaning, letting the sounds take the place of sense. If readers find a way to translate the words, however, they may discover another song embedded in the lines: the gospel-turned-protest song "This Little Light of Mine." ${ }^{16}$ Written for children in the 1920s, "This Little Light" became an anthem for the Civil Rights Movement of the 1960s. By translating the anthem's lyrics into Muscogee and singing them from her present location on Muscogee stomp grounds, Harjo's speaker reactivates the power of song to protest shared histories of enslavement and remember the unfinished business of Civil Rights. By rewriting, embodying, and relocating this song, Harjo activates deep resonances between Black and Native traditions of resistance. And, as she voices these lower frequencies, she prepares her readers and listeners to hear clearly, perhaps for the first time, the urgent message she writes on the facing page: "To understand each other is profound beyond human words. This is what I am singing" (55).

\section{Conclusion}

69 "[A] musical art form that grew on American soil out of the interaction of the very different African and European musical traditions," jazz music tells stories that function as "messengers and ambassadors between the world's cultures" (Giddens xiii). As jazz has traveled from one location to another, or from the stage or studio to the written page, its voices and forms have provided opportunities for writers to articulate the symbolic and political potential of night as an imaginary space for active and engaged resistance.

70 In their various representations of night and adaptations of jazz forms, Langston Hughes and Joy Harjo created poems in which relations across cultures, generations, and races reverberate. Their poetry bridges modernity's fragmentation of time and coloniality's mastery of space through forms always in the process of revision and transformation, creating the potential for alliances across places and cultures. Hughes 
and Harjo confront the "darker sides of modernity," but they also promise access to previously unspoken knowledge and to new languages for expressing individual and collective identities.

Darkness signifies so powerfully in the American imagination, Toni Morrison's collection of essays Playing in the Dark attests, in great part because it evokes violent histories of coloniality, racism, and oppression. Morrison proposes, however, that attention to patterns of darkness and light in American literature can potentially open a new and vast "space for discovery, intellectual adventure, and close exploration" of territory that can be imagined as located outside of "the mandate for conquest" (3). "American Nights" in jazz poetry might be considered as entryways to those dark, undiscovered spaces that Morrison envisions, spaces in which modernity's racial histories continue to be explored, articulated, and resisted. As imagined through poetry, such spaces powerfully translate the temporality of night into occasions for individual self-realization and moments for mobilizing collective action.

\section{BIBLIOGRAPHY}

Ake, David. Jazz Matters: Sound, Place, and Time Since Bebop. Berkeley: University of California Press, 2010.

Anderson, Paul. Deep River: Music and Memory in Harlem Renaissance Thought. Durham: Duke University Press, 2001.

Andrews, Jennifer. "Native American Women Poets." A History of Twentieth Century Women's Poetry. Ed. Linda Kinnahan. New York: Cambridge University Press, 2016. 75-89.

Berendt, Joachin-Ernst and Günther Huesmann. The Jazz Book: From Ragtime to the $21^{\text {st }}$ Century. Seventh Edition. Trans. H. and B. Bredigkeit, Dan Morgenstern, Tim Nevill, and Jeb Bishop. Chicago: Lawrence Hill Books, Chicago Review Press, 2009.

Berglund, Jeff, Jan Johnson, and Kimberli Lee (eds.). Indigenous Pop: Native American Music from Jazz to Hip Hop. Tucson: University of Arizona Press, 2016.

Bitsui, Sherwin. Interview with Joy Harjo. Bomb (5 December 2018). 14 January 2020.

$<$ https://bombmagazine.org/articles/sherwin-bitsui/>

Brooks, Gwendolyn. Selected Poems. New York: Harper, 1963.

Byrd, Jodi A. Transit of Empire: Indigenous Critiques of Colonialism. Minneapolis: Minnesota University Press, 2011.

Corso, Gregory. “For Miles.” In Jazz Poems. Ed. Kevin Young. New York: Knopf, 2006. 114.

Davis, Miles.'Round About Midnight. Columbia/Legacy. Miles Davis, trumpet; Thelonious Monk, piano, Percy Heath, bass; Connie Kay, drums. Newport, R.I.: July 17, 1955.

Diamond, Beverly. "Native American Contemporary Music: The Women." The World of Music. Vol 44, no. 1. Indigenous Popular Music in North America: Continuations and Innovations. Berlin: Verlag fur Wissenschaft und Bildung, 2002. 11-39. 
Edwards, Brent Hayes. The Practice of Diaspora: Literature, Translation, and the Rise of Black Internationalism. Cambridge: Harvard University Press, 2003.

Early, Gerald (ed.). Miles Davis as American Culture. Chicago: Missouri History Museum/University of Chicago Press, 2001.

Ellison, Ralph. The Collected Essays of Ralph Ellison. Edited by John F. Callahan. New York: Modern Library, 1995.

Fast, Robin Riley. The Heart as a Drum: Continuance and Resistance in American Indian Poetry. Ann Arbor: University of Michigan Press, 2000.

Feinstein, Sasha and Yusef Komunyakaa (eds.). The Jazz Poetry Anthology. Bloomington: Indiana University Press, 1991.

--- (eds.). The Second Set: The Jazz Poetry Anthology, Volume 2. Bloomington: Indiana University Press, 1996.

Fikes, Betty. “This Little Light of Mine.” Smithsonian Folkways Recording. 14 January 2020.

$<$ https://folkways.si.edu/betty-fikes/this-little-light-of-mine/african-american-musicdocumentary-struggle-protest/track/smithsonian>

Friedman, Susan Stanford. Planetary Modernisms: Provocations on Modernity Across Time. New York: Columbia University Press, 2015.

Giddens, Gary. Visions of Jazz. New York: Oxford UP, 1998.

Goeman, Mishuana. Mark My Words: Native Women Mapping Our Nations. Minneapolis: U of Minnesota Press, 2011.

Griffin, Farah Jasmine. “Ladies Sing Miles.” Miles Davis and American Culture. Ed. Gerald Early. Chicago: Missouri History Museum/University of Chicago Press, 2001. 181-87.

Harjo, Joy. “An American Sunrise.” Poetry. February 2017. 14 January 2020.

<https://www.poetryfoundation.org/poetrymagazine/poems/92063/an-american-sunrise>.

---. An American Sunrise. New York: W. W. Norton, 2019.

---. Conflict Resolution for Holy Beings. New York: W.W. Norton, 2015.

---. How We Became Human: New and Selected Poems. New York: W. W. Norton, 2002.

---. A Map to the Next World: Poems and Tales. New York: W. W. Norton, 2000.

--- and Tanaya Winder. Soul Talk, Song Language. Wesleyan UP, 2011.

Harris, Craig. Heartbeat, Warble, and the Electric Powwow: American Indian Music. Norman: University of Oklahoma Press, 2016.

Hobby, Susan Thornton. “The Craft of Soul Talk: Interview with Joy Harjo.” Soul Talk, Song Language: Conversations with Joy Harjo. Ed. Tanaya Winder. 79-86.

Hughes, Langston. The Collected Poems of Langston Hughes. Eds. Arnold Rampersad and David Roessel. New York: Vintage Books, 1994.

---. The Collected Works of Langston Hughes. Volume 9. Ed. Christopher C. De Santis. Columbia: University of Missouri Press, 2002.

Johnson, Jan. "'We Were All Wounded at Wounded Knee': The Engaged Resistance of Folk and Rock in the Red Power Era." Indigenous Pop: Native American Music from Jazz to Hip Hop. Eds. Jeff Berglund, Jan Johnson, and Kimberli Lee. Tucson: University of Arizona Press, 2016. 92-10 
Kim, Seong-Hon. “Oral Tradition, Activist Journalism and the Legacy of 'Red Power': Indigenous Cosmopolitics in American Indian Poetry.” Arizona State University, 2014.

Komunyakaa, Yusef. Testimony: A Tribute to Charlie Parker. Middleton, CT: Wesleyan University Press, 2013.

Lincoln, Kenneth. Sing with the Heart of a Bear: Fusions of Native and American Poetry. Berkeley: University of California Press, 2000.

Monsen, Ingrid. Saying Something: Jazz Improvisation and Interaction. U of Chicago Press, 1997.

Morrison, Toni. Playing in the Dark: Whiteness and the Literary Imagination. New York: Vintage, 1993.

“A Night at the Cotton Club: Music of Duke Ellington, Harold Arlen \& Cab Calloway." Riverwalk Jazz Collection, Stanford University. 14 January 2020.

$<$ http://riverwalkjazz.stanford.edu/program/night-cotton-club-music-duke-ellington-haroldarlen-cab-calloway>.

Ongiri, Amy Abugo. Spectacular Blackness: The Cultural Politics of the Black Power Movement and the Search for a Black Aesthetic. Charlottesville: University of Virginia Press, 2010.

Redmund, Eugene B. “A Harbor of Sense: An Interview with Joy Harjo." Crossing Waters, Crossing Worlds: The African Diaspora in Indian Country. Eds. Tiya Miles and Sharon P. Holland. Durham: Duke University Press, 2006. 25-30.

Rios, Gabriela Raquel. “'We'll Get There with Music': Sonic Literacies, Rhetoric's of Alliance, and Decolonial Healing in Joy Harjo's Winding Through the Milky Way.” Eds. Jeff Berglund, Jan Johnson, and Kimberli Lee. Tucson: University of Arizona Press, 2016. 107-122.

Share, Don. "Introduction: The Golden Shovel." Poetry Foundation 1 February 2017. 17 January 2020.<https://www.poetryfoundation.org/poetrymagazine/articles/92023/ introduction-586e948ad9af8>.

Siegel, Bill. "Jazz and the Politics of Identity: The Spirit of Jim Pepper." Indigenous Pop. Eds. Jeff Berglund, Jan Johnson, and Kimberli Lee. Tucson: University of Arizona Press, 2016. 47-60.

Smethhurst, James. “'Don't Say Goodbye to the Porkpie Hat': Langston Hughes, the Left, and the Black Arts Movement.” Calalloo 25.4 (2002): 1225-1236.

Teaton, Sean Kicummah. Red Land, Red Power: Grounding Knowledge in the American Indian Novel. Durham: Duke University Press, 2008.

Vogel, Shane. The Scene of Harlem Cabaret: Race, Sexuality, Performance. Chicago: University of Chicago Press, 2009.

Womack, Craig S. Red on Red: Native American Literary Separatism. U of Minnesota Press, 1999.

Young, Kevin, ed. Jazz Poems. New York: Knopf, 2006.

\section{NOTES}

1. For details about The Cotton Club's evening entertainments, see "A Night at the Cotton Club: Music of Duke Ellington, Harold Arlen \& Cab Calloway," based on Riverwalk Jazz script by Margaret Moos. 14 January 2020 <http://riverwalkjazz.stanford.edu/program/night-cotton-clubmusic-duke-ellington-harold-arlen-cab-calloway>.

2. Recordings function as active archives, providing musicians with access to a repertoire of standards and writers with private soundtracks. Recordings also encourage creative 
relationships between varied artists. In her study of jazz improvisation as a mode of cultural interaction, Ingrid Monsen notes that while live performances generate complex responses from listeners who perceive the innovation, "transformation, irony, and humor" in a musician's style and recognize allusions according to their own "aural familiarity with the musical repertories and conventions," (123) recordings function as enduring resources for musicians, allowing them to learn "turns, solos, harmonic substitutions, timbral sensibility, or rhythm section styles" (126). 3. Following the lead of Sascha Feinstein, an editor of The Jazz Poetry Anthology and author of Jazz Poetry: From the 1920s to the Present, in this essay I work with a broad, brief definition: "A jazz poem is any poem that has been informed by jazz music" and reveals a rich "synesthesia of musical and literary innovations" (Feinstein 1997, 2).

4. For Friedman, jazz is a musical form that fully expresses the creative resistance of the modern colonial subject. Following Paul Gilroy's argument in The Black Atlantic, she pursues the artistic expressions of the descendants of people forcibly removed from African and "enslaved in the New World-alienated, exiled, transplanted, and infinitely creative. And in that new world," she writes, "their descendants blended European and African musics to create creolized musical forms that have themselves transformed, traveled, and transplanted through the planet" (Friedman 62).

5. See Hughes, "Jazz as Communication," in Hughes 2002, 370.

6. According to James Smethhurst, Hughes not only provided literary models for this later generation; he also mentored young artists and critiqued their work, "reminding the younger artists of a long tradition of black radicalism in the arts while chiding older artists and intellectuals for our own cultural amnesia about their radical youth" (1225).

7. The Black Aesthetic, the Black Arts Movement's definitive text edited by Addison Gayle, emphasized "music, poetry, and drama, forms that are not only primarily communal but also have their foundations in African American oral folk cultures" (Ongiri 104). All three forms fostered the collective expression of Black communities and collaborative aesthetics, but music more immediately engaged the productive tensions between tradition and innovation at the center of the movement's revolutionary aesthetic (Ongiri 24).

8. See Harjo 2015, 19.

9. For more detailed exploration of these intersections, consult the essays in Indigenous Pop.

10. See Mark My Words, Chapter 3, for Goeman's analysis regarding how Harjo sees music as a means of accessing "dark" history and approaches poetry and music as "one entity" capable of rendering "places that converge with multiple temporalities" (Goeman 125).

11. Ellison's essay "On Bird, Bird-Watching and Jazz" considers "why, during a period when most jazzmen were labeled 'cats,' someone hung a bird on Charlie" (67). He decides that Parker most resembles a mockingbird due to its type of song, facility with mimicry, and its association with the night. For Ellison, Parker's "mocking mimicry of other jazzman's styles" and his "interpolations of motifs from extraneous melodies" all "added up to a dazzling display of wit, satire, burlesque, and pathos" (68).

12. To hear Harjo reading "An American Sunrise," go to the Poetry website: <https:// www.poetryfoundation.org/poetrymagazine/poems/92063/an-american-sunrise>

13. In the version of the poem published in the 2019 book, Harjo revises the rhythm through punctuation and capitalization and rewrites many lines. The most significant change comes at the end: she omits the last two lines and concludes, simply, with "We." Perhaps less confident now that "rumors of [Native] demise" can be spit out, or perhaps refusing to repeat the sentence "We die soon," she nonetheless utters a final declaration of collective presence.

14. See Seong-hon Kim, "Oral Tradition, Activist Journalism and the Legacy of 'Red Power'," for an account of Harjo's involvement in the Red Power movement.

15. For a thorough analysis of the song as performed on the album, consult Rios 120-1. 
16. To access the lyrics and listen to a recording of "This Little Light of Mine" made for Smithsonian Folkways, consult < https://folkways.si.edu/betty-fikes/this-little-light-of-mine/ african-american-music-documentary-struggle-protest/track/smithsonian>.

\section{ABSTRACTS}

While popular music has long been recognized as central to the Black Power movement and its writers, jazz has also served as a mode of decolonial thinking for Red Power writers. This essay investigates the places where jazz poetry emerged, analyzes the meanings of darkness, and listens for deep connections between African American and Native American artists and their musical cultures. My analysis of selected examples of jazz poetry, from Langston Hughes's foundational jazz and blues poems to more recent compositions by Yosef Komunyakaa and Joy Harjo, shows how jazz has traveled across racial, cultural, and gender divides to disrupt time, to articulate the symbolic and political potential of night, and to reconnect printed poetry with aural performance. In the process, I argue, jazz poetry reveals critical intersections between race and culture and creates new spaces for active and engaged resistance.

Alors que la musique populaire est depuis longtemps reconnue comme essentielle au mouvement Black Power et à ses écrivains, le jazz sert aussi de mode de pensée décoloniale aux auteurs du Red Power. Cet article explore les lieux où la poésie jazz est née, analyse les acceptions de l'obscurité, et cherche à faire entendre les connections profondes entre les artistes afroaméricains et amérindiens et leurs cultures musicales. Mon analyse de quelques exemples de poésie jazz, depuis les poèmes blues et jazz fondateurs de Langston Hughes jusqu'aux compositions plus récentes de Yosef Komunyakaa et Joy Harjo, montre comment le jazz a traversé les frontières raciales, culturelles, et de genre pour transformer le temps, exprimer la portée symbolique et politique de la nuit, et recréer le lien entre le texte poétique et la performance orale. De cette façon, la poésie jazz met en lumière des intersections cruciales entre identité et culture, et crée de nouveaux espaces de résistance active et engagée.

\section{INDEX}

Keywords: night, jazz poetry, blues, break, emergence, Red Power, Black Power, modernity, coloniality, Native American music, Native homelands

Mots-clés: nuit, poésie jazz, blues, break, émergence, Red Power, Black Power, modernité, colonialité, musique amérindienne, pays natal

\section{AUTHORS}

\section{AUDREY GOODMAN}

Professor

Georgia State University

agoodman@gsu.edu 